\title{
THE ESSENCE AND ROLE OF REGULATORY REFORM
}

\author{
Lecturer PhD Student Rodica Tiron, Academy of Economic Studies of Moldova, \\ rodica_z@yahoo.com
}

\begin{abstract}
This paper presents the essence and the role of regulatory reform in the process of regulations in economy doing by government. The article analyses the theoretical aspects according to the stages of regulatory reform, such as: deregulation, regulatory quality improvement, regulatory management. Regulatory reform can help address regulatory deficiencies that negatively affect the overall competitiveness of firm on the national or international place. We consider, that the complex approach of the regulatory reform process, with the involvement of public authorities and the representatives of the private sector, will contribute substantially at the reduction of the barriers in the lasting development and will create real premises of the economic increase of the country.
\end{abstract}

Key words: regulatory reform, stages of regulatory reform, deregulation, quality of regulations, principles of regulation, regulatory management.

JEL codes: $G 38$

Any stage of development of an economy is based on a regulatory environment that involves the insurance of a more simplified regulation, more clear and capable to provide informational contribution for the development and the support of all participants in the economy, so to obtain an improvement of the performance and competitiveness of the national economy, and an increased of her ability to adapt and to innovate in concordance with the tempo of development of the entire society.

Thus, the regulatory environment includes processes and institutions through which the regulations are analyzed, enriched, promoted (approved) and revoked intermediary by the regulatory reform. In this context, the regulatory reform started as a response of the necessity to decrease the strong regulations and legislative burden, occurred in the past, trough the significant government interventions (especially on the small business sector), which limited the competition.

The analysis of regulatory reform involves its appreciation trough the position at the following stages: the deregulation, the improvement of the quality of regulation, the regulatory management. The increased the control and the discipline of the regulatory reform conditioned its maturity passing from the "deregulation" to the "improvement of the quality of regulation" and the latter turning into the "regulatory management".

The deregulation represents the complete or partial withdrawal of government control and restrictions to a specific activity. Deregulation, a term which gained widespread currency in the period 1970-2000, can be seen as a process by which governments remove, reduce, or simplify restrictions on business and individuals with the intent of encouraging the efficient operation of markets. The stated rationale for deregulation is often that fewer and simpler regulations will lead to a raised level of competitiveness, therefore higher productivity, more efficiency and lower prices overall.

The objectives of reform in the stage of deregulation are:

- the elimination of the regulations that hinder the competition and the dealings;

- the diminution of the number of regulations;

- the decreasing of the burden and of the regulatory costs, especially in the small business; 
- the simplification of regulatory processes;

- the administrative improvement, etc.

As regulatory reform in the stage of deregulation in the Republic of Moldova, can serve the approval in 2005 of the Law referring to the revision and the optimization of normative regulatory code of the entrepreneur activity, called the Guillotine Law (I). This law establishes the principles and necessary actions to revise the existent regulatory code, in order to optimize the regulatory code of entrepreneurial activity and to eliminate the regulations which do not correspond to the legislation and present barriers for the development of the business environment.

The "Regulatory Guillotine" concept was elaborated in 1980 in Sweden and has as aim to revise quickly a large number of regulations with the elimination of their which do not correspond to the legally and market principles. The Regulatory Guillotine was applied in several countries including Italy, Mexico, South Korea, and Hungary, as modern lever of the politics and of the regulatory reform.

In accordance with the stipulations of the "Guillotine" Law the revision of normative acts in Republic of Moldova was developed in three stages. At the first stage of revision of normative acts, each authority of the public administration examined the official acts of its field of activity and was presented to the Working Group of the state Commission. The second stage included the examination and the detailed revision of official acts and of the notes presented by the authorities of public administration in the Working Group. At the third stage of implementation of the "guillotine" Law it was assured the participation of the large public. As a result of the examination, the normative acts which regulate the entrepreneur activity were grouped as follows:

- official acts which correspond to the provisions of the "guillotine" Law;

- official acts which infringe to the provisions of the "guillotine" Law and should be repealed;

- acts issued by the independent structures which infringe to the provisions of the "guillotine" Law and should be recommended for repeal;

- acts which do not correspond completely with the "guillotine" Law, but their repeal at present is unseasonable because of the danger of apparition a void in the regulatory code.

The increase (the improvement) of the quality of regulation is the next stage of the regulatory process. At this stage it is emphasized the quality of regulation, which is a neutral concept regarding the respect of the level and the field of government intervention. Different countries are entitled to pursue different regulatory politics - the aim is to ensure that those regulations should be applied only when it is necessary and used efficient, effective and transparent on how it is possible.

The basic principles which have as aim to govern the unrolled actions in the improvement context of the quality of regulation are:

- The principle of proportionality - the offered solutions must not exceed what is necessary to achieve the established objectives trough the adopted regulations, they must be in the order of issues or identified risks;

- The principle of accountability - the initiators of the regulations must justify, in a transparent manner, the proposed solutions;

- The principle of consistency - the regulations must be fair and be applied in a unitary and coherent manner. The default of this principle may create large uncertainties in the private sector, and may have negative and serious effects regarding the investments;

- The principle of transparency - the regulations should be let known to the interested parts. This principle implies that the regulatory process to be presented to the public and appreciating the decisions, the consultations and the regulatory problems;

- The principle of specificity - the regulations must pursue the resolution of a problem, the secondary effects, and their negative consequences.

The principles enumerated above lie at the basis what insurance a higher level of the quality regulatory process. Because, the regulation, in a large measure, has a significant impact on the 
entrepreneur activity, the Governments of countries members of OECD have approved a guide of the principles of corporate government in 2004. The origin of this set of principles includes the common elements of the most efficient codes and practices of good government.

In the Republic of Moldova in 2006 was approved the Law referring to the basic regulatory principles of the entrepreneur activity. According to these principles, the implementation of an effective system of corporatist government should be lead to a transparency and efficiency of markets, to be compatible with the state of law and to define clearly the repartition of responsibilities between the competent instances in monitoring matter, of regulation and application of the lawful provisions.

Thus, the regulation of entrepreneur activity signifies the determination of the rights, obligations, requirements and prohibitions regarding the entrepreneurs and their activity, as well as the regulation of relations between the public authorities and entrepreneurs. The creation of a favorable juridical code will encourage the business environment and the investment climate for a socio-economic development of the country. The implemented strategies for the improvement of the quality of regulation are presented and oriented towards three compartments:

A: The organization of a managerial regulatory system, which supposes:

- the adoption of a regulatory reform politics at the highest levels;

- the explicit (clear) determination of the standards of qualitative regulation and of the principles of regulation;

- the creation, the improvement, the increase of the management skills in the regulation.

$B$ : The promotion of the quality of new regulations (flow):

- the use of Regulatory Impact Analysis (RIA). AIR is a term used to describe the process of systemic analysis of the benefits and the costs of a new regulation, with the aim to improve the quality of the regulatory politics. The respective analyses appreciate the negative or positive impact of a new regulation or of the existent regulations. From 01 January 2008, the implementation of AIR procedure in the Republic of Moldova became compulsory as result of the change of the law no. 235-XVI from 20.07.2006 concerning the basic principles of entrepreneur activity by the Law no. 182-XVI from 20.07.2007. Thus all normative acts succeed in the address of Working Group for the regulation of the entrepreneurs activity are followed by an Analysis of the Regulatory Impact ( The Guillotine II);

- Permanent consultations with groups of interests. A comprehensive politics of consultancy will open the regulatory process towards groups of interests and will provide successfully the information about the regulatory impact;

- The use of the alternative regulatory possibilities. A systematic assessment of the regulatory alternatives will help the development of the government (the management, the authorities) more effective, a lower costs of politics instruments;

- the improvement of the regulatory coordination.

C: The development of the existing regulatory quality (stock):

- The analysis and the evaluation of the existent "stock" of regulations for the determination (assessment) if the regulations are effective, without exaggerated negative impacts;

- the decrease of the bureaucracy and of the government formalities.

The regulatory management. The qualitative regulations were concentrated to improve the individual quality (separated only of some component parts) of the regulation, but the most important problems are more profound, resulting for the functioning of the regulatory incorruptible system. In these circumstances it is necessary to know and to develop a management of the regulation.

At this stage of development of the regulatory reform, the reform initiatives become focused on the long-term, more sophisticated as a aim, and more concerned in the elimination of the existent contradictions in the regulatory system. In the developed countries, the regulatory 
management is a basic component in the management of governance, with the apparition of some separate departments. Thus, the building of a regulatory management system of management (regulatory management system) supposes:

- the complex management of the regulatory effects, such as the total costs of the sector;

- the increase of the efficiency of the regulatory system;

- the determination of the orientation structure of participants with the intermediate of the administration;

- the implementation of a regulatory reform for a long-term;

- the management (orientation) of regulations in conditions of globalization;

- the development of regulatory alternatives to a higher level;

- the increase of responsibilities and of the transparency, etc.

Also, at this stage of the regulatory reform, it is necessary the establishment of the regulatory strategy, which in the Republic of Moldova is called the Reform Strategy of the regulatory state code of the entrepreneur activity, approved in 2007. Similarly, it is necessary to mention the necessity to create independent departments in the field analyzed. In 2005, in Republic of Moldova by the Government Decision No. 132 of 08.02.2005, "Concerning the revision and the optimization of the normative code of regulation of the entrepreneur activity" were established by the State Commission for the regulation of entrepreneurial activity and the Work Group, as a body of this Commission.

Of those exposed, we noted that the regulatory reform is the balance between the deregulation on the one hand and the qualitative promotion of the necessary regulations on the other hand. Thus, an effective regulatory reform imposes a multifunctional strategy which pursues (i) the legislation deregulation (where there are unnecessary or dangerous rules), (ii) the quality promotion of existing regulations or of those that will be approved and implemented combined with (iii) the institutional change of the procedures and the creation of the new capacities of the management for the reform (regulatory) promotion and the strictly supervision of the results.

We consider that the complex approach of the regulatory reform process, with the involvement of public authorities and the representatives of the private sector, will contribute substantially at the reduction of the barriers in the lasting development and will create real premises of the economic increase of the country.

\section{References:}

1. Cook P., Kirkpatrick C, Minogue M, Parker D. - Leading Issues in Competition, regulation and development, Editura Edward Elgar Publishing, United Kingdom, 2004, p.464;

2. $* * *$ Legea privind revizuirea şi optimizarea cadrului normative de reglementare a activității de întreprinzător, nr. 424 din 16.12.2004 // Monitorul Oficial nr. 001 din 01.01.2005;

3. $\quad * * *$ Legea cu privire la principiile de bază de reglementare a activității de întreprinzător nr. 235 din 20.07.2006 // Monitorul Oficia nr. 126-130 din 11.08.2006 (cu modificările ulterioare);

4. *** Hotărârea Guvernului Republicii Moldova cu privire la aprobarea Strategiei de reformă a cadrului de reglementare de stat a activității de întreprinzător nr. 104 din 01.02.2007 // Monitorul Oficial nr. 021 din 16.02.2007;

5. $\quad * * *$ Hotărârea Guvernului României privind Strategia pentru o reglementare mai bună la nivelul administrației publice centrale 2008-2013 din 24 septembrie 2008;

6. $* * *$ The OECD Report on Regulatory Reform vol.II: Thematic Studies, Joanna R. Shelton, ed. OECD Publishing, Paris, 1998, p.332; 